University of Nebraska - Lincoln

DigitalCommons@University of Nebraska - Lincoln

$10-2003$

\title{
A New Species of Syncuaria Gilbert, 1927 (Nematoda: Acuarioidea: Acuariidae) in the Wood Stork, Mycteria americana L. (Aves: Ciconiiformes: Ciconiidae) from the Área de Conservación Guanacaste, Costa Rica
}

Luping Zhang

University of Toronto

Daniel R. Brooks

University of Toronto,dnlbrooks@gmail.com

Douglas Causey

University of Alaska Anchorage, dcausey@uaa.alaska.edu

Follow this and additional works at: https://digitalcommons.unl.edu/parasitologyfacpubs

Part of the Parasitology Commons

Zhang, Luping; Brooks, Daniel R.; and Causey, Douglas, "A New Species of Syncuaria Gilbert, 1927 (Nematoda: Acuarioidea: Acuariidae) in the Wood Stork, Mycteria americana L. (Aves: Ciconiiformes: Ciconiidae) from the Área de Conservación Guanacaste, Costa Rica" (2003). Faculty Publications from the Harold W. Manter Laboratory of Parasitology. 233.

https://digitalcommons.unl.edu/parasitologyfacpubs/233

This Article is brought to you for free and open access by the Parasitology, Harold W. Manter Laboratory of at DigitalCommons@University of Nebraska - Lincoln. It has been accepted for inclusion in Faculty Publications from the Harold W. Manter Laboratory of Parasitology by an authorized administrator of DigitalCommons@University of Nebraska - Lincoln. 


\title{
A NEW SPECIES OF SYNCUARIA GILBERT, 1927 (NEMATODA: ACUARIOIDEA: ACUARIIDAE) IN THE WOOD STORK, MYCTERIA AMERICANA L. (AVES: CICONIIFORMES: CICONIIDAE) FROM THE AREA DE CONSERVACION GUANACASTE, COSTA RICA
}

\author{
Luping Zhang, Daniel R. Brooks*, and Douglas Causey $\dagger$ \\ Centre for Comparative Biology and Biodiversity, Department of Zoology, University of Toronto, Ontario, Canada M5S 3G5. e-mail: \\ dbrooks@zoo.utoronto.ca
}

\begin{abstract}
Syncuaria mycteriae n. sp. (Nematoda: Acuarioidea) was collected under the lining of the gizzard of a wood stork, Mycteria americana L., from the Area de Conservacion Guanacaste, Costa Rica. The new species can be distinguished from all known species of Syncuaria by having irregular dotted ornamentations on the caudal alae of males, a complex distal end of the left spicule comprising 3 protuberances, and a spicule ratio of 1:9.3. Preliminary phylogenetic analysis of 11 Syncuaria spp. based on 9 morphological characters produced 2 equally parsimonious cladograms with a consistency index of $85 \%$, differing only in the placement of $S$. hargilae. The phylogenetic analysis suggests that the new species is the sister species of $S$. leptoptili, whose male members have a single protuberance on the left spicule. Furthermore, the analysis suggests that the plesiomorphic host group for the genus is Ciconiiformes, specifically Ciconiidae (host for 5 species), with 2 species occurring in Threskiornithidae (also Ciconiiformes), possibly as a result of cospeciation, and 2 species each occurring in Pelecaniformes and Podicipediformes, resulting from 4 episodes of speciation by host switching.
\end{abstract}

Species of Syncuaria Gilbert, 1927, parasitize freshwater piscivorous birds belonging to the orders Ciconiiformes, Pelecaniformes, and Podicipediformes, in which they are characteristically found under the gizzard lining (Wong et al., 1986). Gilbert (1927) described the first species of Syncuaria, S. ciconiae, inhabiting Ciconia ciconia L. and C. nigra L. in Georgia. Skrjabin et al. (1965) recorded 9 species of this genus. A revision of the genus Syncuaria was made by Wong et al. (1986), who regarded Skrjabinocara Kurashvili, 1940, Chordocephalus Alegret, 1941, and Decorataria Sobolev, 1949, as synonyms of Syncuaria; 9 valid species were recognized, and 6 species were regarded as species inquirendae. Since then, 1 additional species has been added to the genus (Digiani, 1999).

During June 1998, as part of an ongoing biodiversity inventory of the eukaryotic parasites of vertebrates inhabiting the Area de Conservacion Guanacaste (ACG) in northwestern Costa Rica (http://brooksweb.zoo.utoronto.ca/index.html), a new species of Syncuaria was collected from the wood stork, $M y c$ teria americana $\mathrm{L}$. This is the first report of Syncuaria from Mycteria or from Costa Rica.

\section{MATERIALS AND METHODS}

One wood stork, $M$. americana, was collected on 24 December 2001 and examined for parasites. Nematodes collected from beneath the lining of the gizzard were fixed in glacial acetic acid and preserved in $70 \%$ ethanol. They were later cleared in lactophenol for further examination. Drawings were made with a microscopy tube. Measurements were given in micrometers unless otherwise stated. Phylogenetic analyses were performed using standard Hennigian Argumentation (Brooks and McLennan, 2002); results were confirmed using the computer program PAUP 4.0b10*, implemented on a Macintosh G4 867 computer.

\section{DESCRIPTION}

Syncuaria mycteriae n. sp.

(Figs. 1-6)

Diagnosis: Medium sized nematodes. Lateral alae present, beginning at anterior part of the glandular esophagus, far from

Received 15 November 2002; revised 7 April 2003; accepted 7 April 2003.

* To whom correspondence should be addressed.

$\uparrow$ Museum of Comparative Zoology, Harvard University, Cambridge, Massachusetts. the cervical papillae, and extended posteriorly to the posterior part of body. Pseudolabia well developed, with conical apices, each bearing a pair of large cephalic papillae and 1 inconspicuous amphid. Cordons beginning at dorsal and ventral sides of oral opening, continuing posteriorly, anastomosing on lateral sides immediately anterior to small, bifid cervical papillae. Cordons narrow, consisting of wide-serrated, crescent-shaped cuticular plates. Cervical papilla $5.7-8.2 \%$ total body length (TBL) from anterior end. Esophagus clearly divided into short anterior muscular part and long posterior glandular part. Muscular esophagus, 4.1-5.7\% TBL; glandular esophagus, 17.5$26.6 \%$ TBL. Nerve ring located at the level of the anterior end of the muscular esophagus. Excretory pore immediately posterior to nerve ring.

Male $(n=2)$ : Body length $8.83 \mathrm{~mm}, 9.72 \mathrm{~mm}$. Maximum width 259, 259. Cordons 629,673 long. Lateral alae begin at anterior part of glandular esophagus, 600, 665 from the cervical papillae. Buccal capsule 222, 229 long. Muscular esophagus 475, 511 long and 52, 65 wide; glandular esophagus $2.26 \mathrm{~mm}$, $2.59 \mathrm{~mm}$ long and 152, 170 wide. Nerve ring 274, 277 from anterior end, excretory pore 304, 311 from anterior end, and cervical papillae 665, 752 from anterior end. Posterior end of body curved. Caudal alae well developed, 455, 575 long, 5.2$5.9 \%$ TBL, with irregular dotted ornamentations. Four pairs of preanal and 5 pairs of postanal pedunculate papillae present. Sixth pair of postanal papillae sessile, smaller, internal to fifth pair. Spicules unequal and dissimilar. Left spicule $1.41 \mathrm{~mm}$, $1.60 \mathrm{~mm}$ long, slender, with 3 protuberances on distal end (Fig. 5). Right spicule 152, 171 long, broad with simple distal end. Ratio of right spicule-left spicule 1:9.3.

Female $(n=4)$ : Body length 12.9-14.5 mm (13.4 mm). Maximum width 311-340 (332). Cordons 696-858 (784) long. Lateral alae 625-950 (809) from the cervical papillae. Buccal capsule 170-259 (229) long. Muscular esophagus 555-646 (581) long and 65-76 (69) wide; glandular esophagus 2.32-2.59 $\mathrm{mm}(2.44 \mathrm{~mm})$ long, and 178-209 (192) wide. Nerve ring 281319 (300) from anterior end, excretory pore 333-403 (351) from anterior end, and cervical papillae 737-904 (830) from anterior end. Monodelphic. Vulva with anterior and posterior 

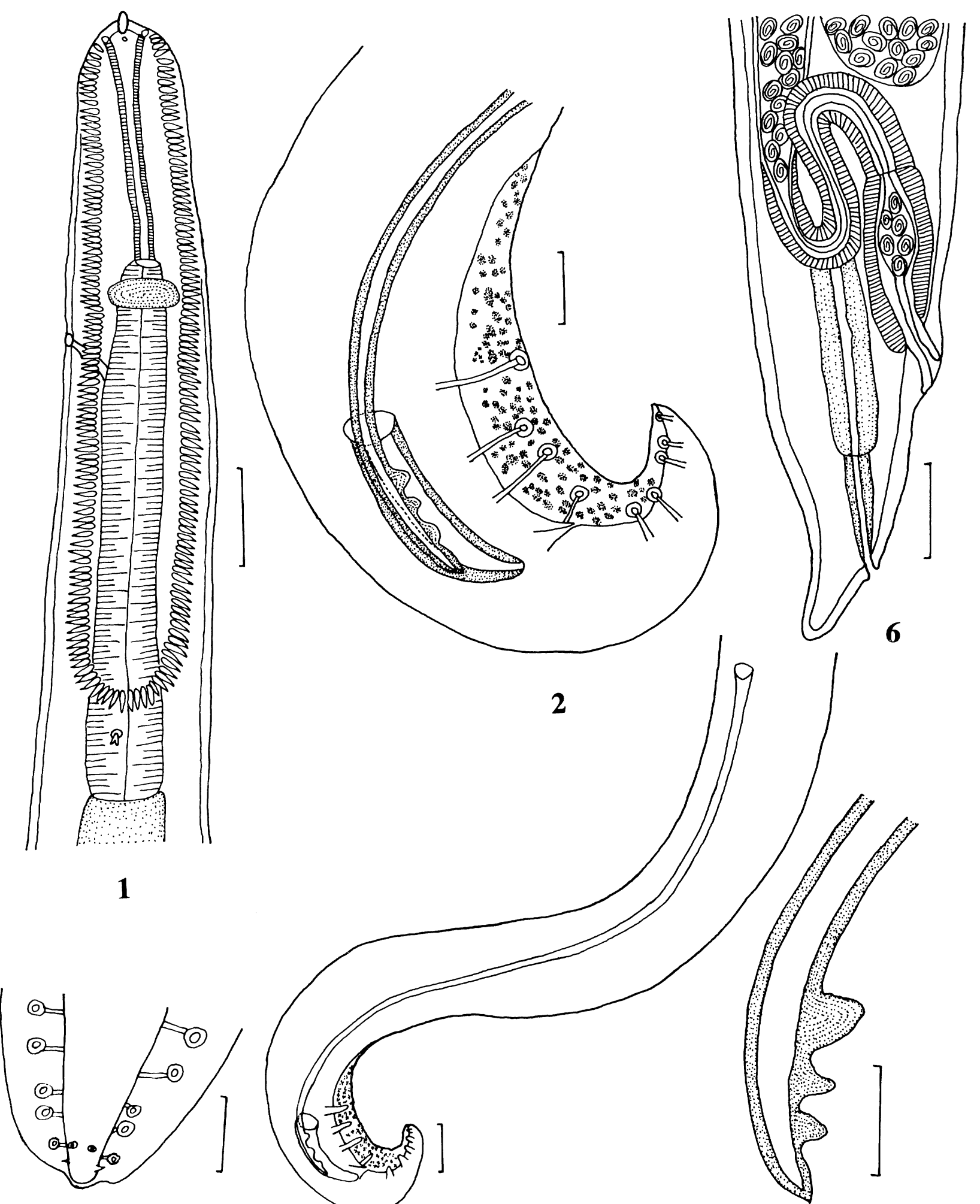

3

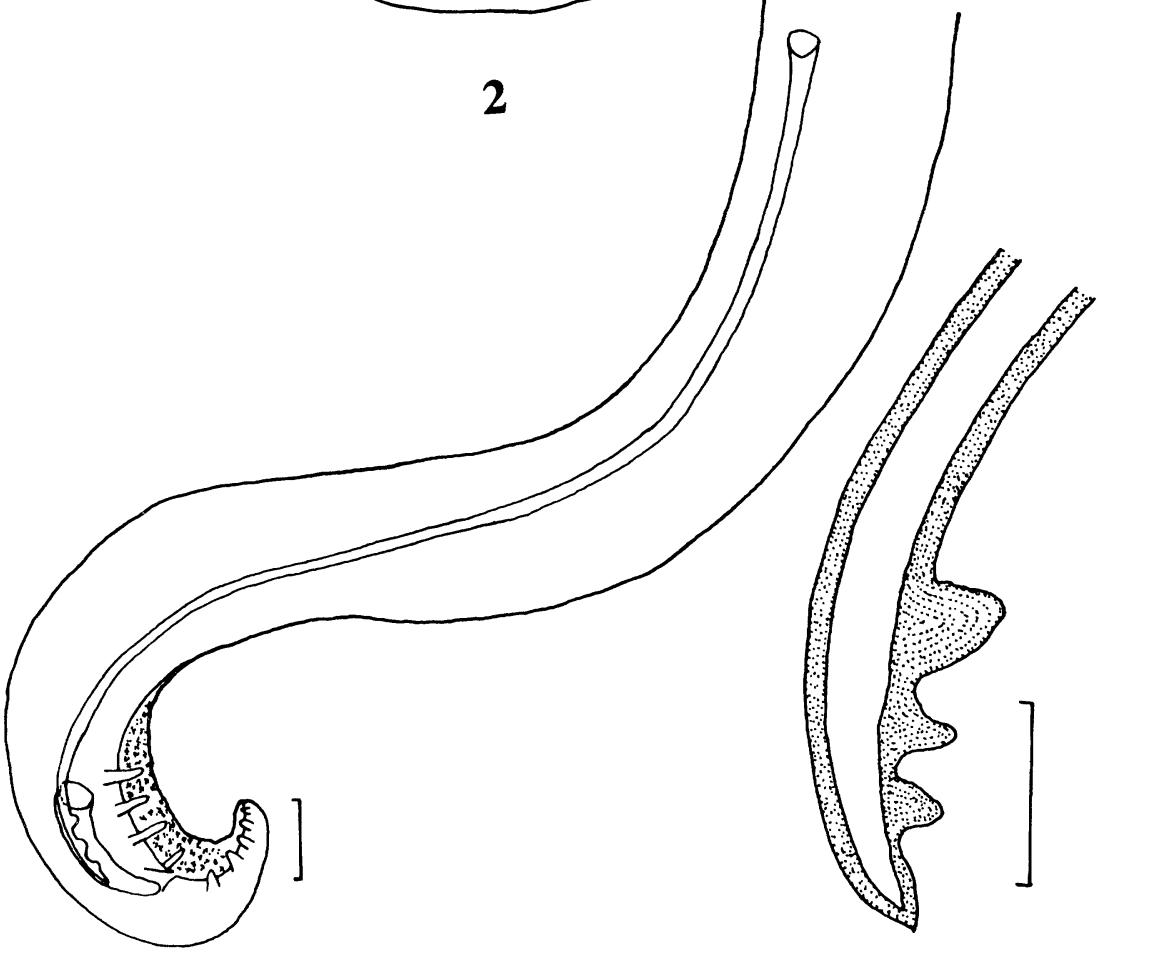

4

5

FIguRES 1-6. Syncuaria mycteriae n. sp. 1. Anterior end of female, lateral view. 2. Posterior end of male, lateral view. 3. Caudal extremity of male, ventral view. 4. Posterior end of male, lateral view showing relative lengths of spicules. 5. Distal end of left spicule. 6. Posterior end of female, lateral view. Bars: 1, 4, $6=100 \mu \mathrm{m} ; \mathbf{2}, \mathbf{3}, \mathbf{5}=50 \mu \mathrm{m}$. 
cuticular inflation, 346-361 (356) from posterior end, 2.5-2.8\% (2.7\%) TBL from posterior end. Ovijector consisting of 2 parts; vagina vera short, 174 long, thickly muscled; vagina uterina longer, 412 long, muscles weaker than that of vagina vera. Tail short, 65-106 (90) long, rounded, curved slightly dorsally. Eggs oval, thick shelled, embryonated, 26-28 (27) long, and 18-20 (19) wide.

\section{Taxonomic summary}

Type host: Mycteria americana L. (Aves: Ciconiiformes: Ciconiidae).

Type locality: Area de acampar, Sector Santa Rosa, ACG, Guanacaste Province, Costa Rica.

Site of infection: Under the lining of the gizzard.

Prevalence and intensity: Two males and 4 females in 1/1 host examined.

Type specimens: Holotype, USNPC 93541; allotype, USNPC 93542; paratype, USNPC 93543.

Etymology: The new species is named after its host genus.

\section{Remarks}

Wong et al. (1986) recently revised Syncuaria thoroughly. The new species can be readily distinguished from all known species of the genus by having irregular dotted ornamentations on the male caudal alae, by having a complex distal end of the left spicule comprising 3 protuberances, and by having a spicule ratio of $1: 9.3$ versus a range of $1: 2.1-6.0$ due primarily to having a longer left spicule than other species. The new species can be further distinguished from $S$. ciconiae Gilbert, 1927, S. decorata (Cram, 1927), S. diacantha Petter, 1961, S. longialula Wang, 1976, and S. plegadisi Digiani, 1999, by the presence of lateral alae.

Among the species having lateral alae, $S$. mycteriae can be distinguished from S. bressoui Gretillat, 1970, and S. hargilae (Baylis and Daubney, 1923) in having a longer left spicule (1,410-1,600 vs. 331-351 in S. bressoui and 595 in S. hargilae) and thus a different spicule ratio (1:9.3 vs. 1:3.9-4.5 in S. bressoui and 1:3.2 in $S$. hargilae). It further differs from $S$. hargilae in having the vulva 346-361 versus 100-102 from the posterior end. The new species differs from S. buckleyi (Ali, 1957) in having longer left and right spicules (1,410-1,600 and 152-171 vs. 450 and 75 , respectively) and in having a spicule ratio of 1:9.3 versus 1:6.0. The new species also differs from the latter in the number of pairs of postanal papillae ( 5 vs. 3 ).

The new species appears to be most similar to $S$. leptoptili (Gedoelst, 1916) and S. squamata (Linstow, 1883) by having narrow cordons consisting of wide-serrated, crescent-shaped cuticular plates but has a longer left spicule $(1,410-1,600$ vs. $850-$ 920 in S. leptoptili and 880-1,020 in S. squamata) and thus a different spicule ratio (1:9.3 vs. 1:4.8-6.0 in S. leptoptili and 1:5.4-5.7 in $S$. squamata). Of these species, $S$. leptoptili is the only other member of the genus for which a nonsimple distal end of the left spicule has been reported, but $S$. mycteriae has 3 protuberances on the distal end of the left spicule (Fig. 5), whereas $S$. leptoptili has only 1 .

The monophyly of Syncuaria has not been established, but among acuarids, species assigned to this genus share the following traits only with members of Desportesius and Skrjabinoclava: monodelphy, vulva near the anus, and a short female tail. Members of all 3 genera also share more general traits of having anastomosing cordons. Desportesius spp. differ from Syncuaria spp. by having posteriorly expanded cordons that may be spined rather than uniformly thin or uniformly wide cordons, whereas Skrjabinoclava spp. differ from Syncuaria spp. by having narrow rather than well-developed caudal alae. Finally, the cephalic cordons in Syncuaria spp. are never recurrent, whereas they are reported as always recurrent in Desportesius and recurrent or not in Skrjabinoclava. We have summarized our above comparisons among species of Syncuaria phylogenetically on the basis of a suite of 9 characters listed below. Character states are taken from the revision by Wong et al. (1986) and the redescription of S. decorata by Baylis (1937) in addition to our specimens of $S$. mycteriae. Determination of plesiomorphic condition was based on out-group comparisons using primarily published reports of Desportesius and Skrjabinoclava:

1. Length of right spicule-0: $140-190 ; 1:>200 ; 2: 85-140$; 3: 74-90.

2. Length of left spicule-0:500-750;1: 850-1,020;2: 1,406-1,596; 3: 1,010-1,390; $4:<500$.

3. Number of pairs of postanal papillae-0: 6 , all papillose; 1: 5 papillose and 1 sessile; 2: 5 papillose and 2 sessile; 3: 5, all papillose; 4: 4, all papillose; $5: 3$, all papillose.

4. Lateral alae-0: present; 1: lacking.

5. Cuticular ornamentation on caudal alae of male-0: lacking; 1: present.

6. Form of cervical papillae-0: bifid; 1 : simple; 2 : tricuspid.

7. Average spicule ratio-0: greater than $1: 5$ but less than 1 : 6; 1: greater than $1: 4$ but less than $1: 5 ; 2$ : greater than $1: 3$ but less than $1: 4 ; 3:<1: 3 ; 4: 1: 9.3$.

8. Cordon width-0: narrow; 1: wide (condition found in $S$. decorata and $S$. diacantha; for comparisons, see figures in Wong et al., 1986).

9. Distal end of left spicule-0: simple; 1: 1 projection; 2: 3 projections.

Phylogenetic systematic analysis of these characters, all run unordered, produced 2 equally parsimonious cladograms (Fig. 7), each with a consistency index of $85 \%$ (a tree length of 27 steps for 23 apomorphic character states). The trees differ only with respect to their placement of $S$. hargilae based on whether lateral alae, once lost, can be regained evolutionarily (represented by the reversal to character state $4(0)$ in Fig. 7 b). Some might consider characters 1,2 , and 7 to be different manifestations of the same trait, but the distribution of apomorphic traits on the trees suggests that they have evolved relatively independently. Finally, despite the very high consistency index in this preliminary analysis, basal relationships within the group are not well resolved, indicating that additional study of these species, as well as their putative sister groups, is needed.

\section{DISCUSSION}

This report brings the number of species of Syncuaria currently recognized as valid to 11 . Seven of these species inhabit Ciconiiformes, 2 inhabit Podicipediformes, and 2 inhabit Pelecaniformes. Five of the 7 species inhabiting Ciconiiformes are parasites of Ciconiidae (storks): S. ciconiae in C. ciconia L. from Georgia (Gilbert, 1927) and C. nigra L. from Georgia and Czechoslovakia (Macko, 1964); S. bressoui in Leptoptilos cru- 


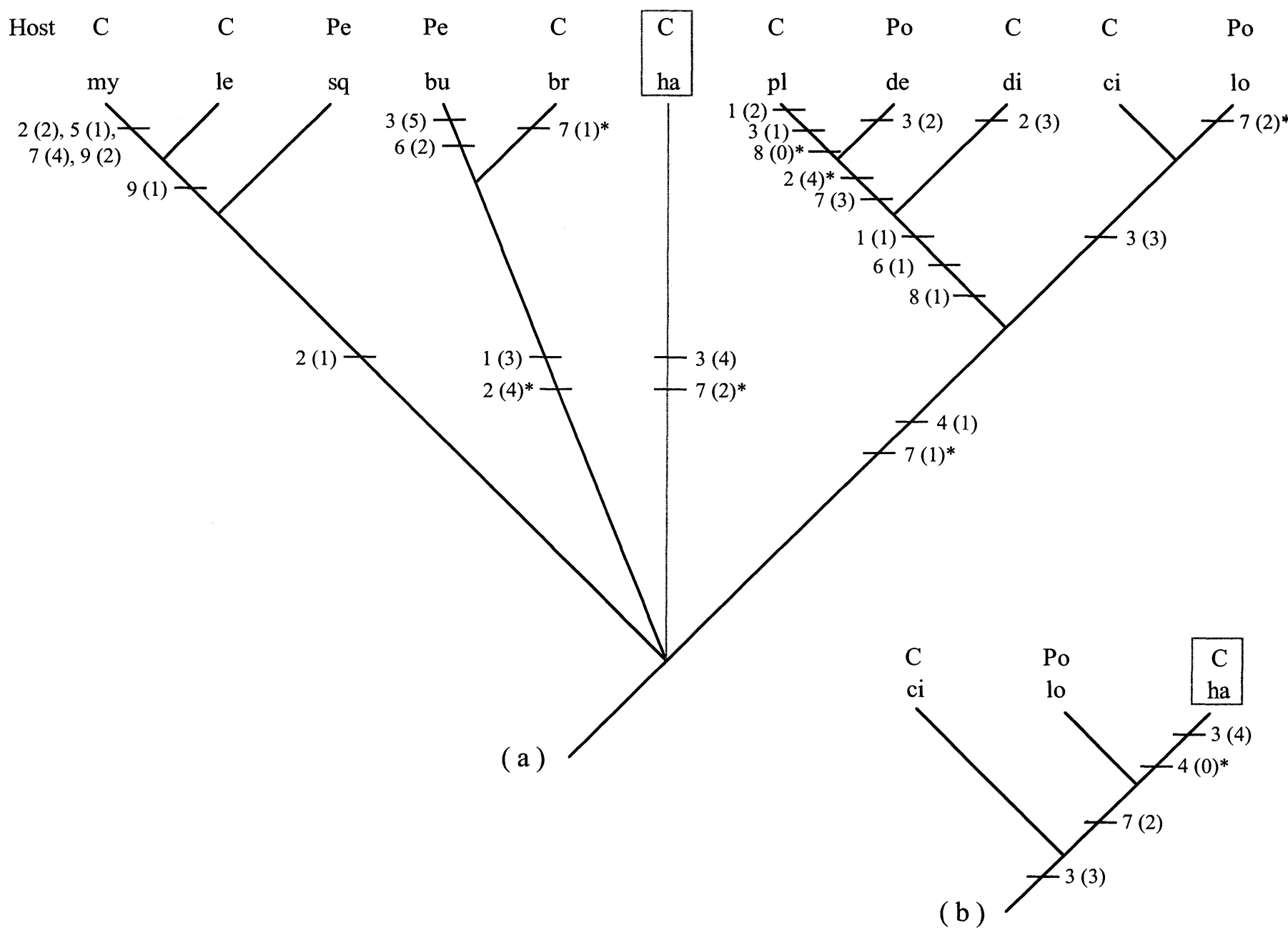

FIGURE 7. Two equally parsimonious cladograms for species of Syncuaria based on 9 morphological characters. Numbers accompanying slash marks on branches of the trees represent putative synapomorphies for characters and their states (listed in parentheses): for identities of characters and states see text. $\mathrm{my}=S$. mycteriae; le $=S$. leptoptilos; $\mathrm{sq}=S$. squamata; bu $=S$. buckleyi $;$ br $=S$. bressoui; ha $=S$. hargilae; $\mathrm{pl}=S$. plegadisi; $\mathrm{de}=S$. decorata; $\mathrm{di}=S$. diacantha; $\mathrm{ci}=S$. ciconiae; $\mathrm{lo}=S$. longialula . Letters associated with line labeled "Host" represent orders of avian hosts: $\mathrm{C}=$ Ciconiiformes, $\mathrm{Po}=$ Podicipediformes, and $\mathrm{Pe}=$ Pelecaniformes.

menifer (Lesson) from Senegal (Gretillat, 1970); S. hargilae in L. dubuis (Gmelin) from India (Baylis and Daubney, 1923); $S$. leptoptilos in L. crumenifer from Congo and Nigeria (Gendre, 1919) and Senegal (Gretillat, 1970) and in C. ciconia and $C$. nigra from Czechoslovakia (Macko, 1962); and S. mycteriae $\mathbf{n}$. sp. in $M$. americana (wood stork) from Costa Rica (this report). The remaining 2 species inhabiting Ciconiiformes are parasites of Threskiornithidae (ibises and spoonbills): $S$. diacantha in captive specimens of Ajaja ajaja (=Platalea ajaja) from France (Petter, 1961) and in wild specimens of the same host from Cuba (Barus, 1966), the United States (Sepulveda et al., 1994), and Argentina (Digiani, 1999) and S. plegadisi in Plegadis chihi from Argentina (Digiani, 1999). The 2 species inhabiting Podicipediformes are parasites of Podicipedidae (grebes): $S$. decorata in Podiceps auritus (L.) from the United States (Cram, 1927), in Podiceps griseigena, Podiceps cristatus, and Podiceps nigricollis from Kyrgistan, Russia, and Azerbaizhan (Shigin, 1957; Iksanov and Dikambaeva, 1965; Vaidova, 1965), in $P$. cristatus from Estonia (Jogis, 1963), in P. cristatus and P. griseigena from Kazakhstan (Gvozdev and Kasimzhanova, 1965), and in P. cristatus, $P$. nigricollis, and Podiceps ruficollis from Czechoslovakia (Barus and Zajicek, 1967) and $S$. longialula in P. nigricollis from China (Wang, 1976). Finally, the 2 species inhabiting Pelecaniformes are parasites of Phalacrocoracidae (cormorants): S. squamata in Phalacrocorax carbo from "Central Asia" (Linstow, 1883) and Azerbaidzhan, Armenia, Georgia, and Turkmenistan (Wong et al., 1986), in P. carbo and Phalacrocorax pygmaeus from Kazakstan and Romania (Roman-Chiriac, 1965), in Phalacrocorax auritus floridanus from Cuba, and in P. a. auritus from Canada (Wong et al., 1986) and $S$. buckleyi (Ali, 1957) in Phalacrocorax niger (Vieillot) from India (Ali, 1957).

The cladogram (Fig. 7) supports an interpretation that Ciconiiformes and specifically Ciconiidae are the plesiomorphic host groups for Syncuaria spp. Threskiornithidae appears to be the plesiomorphic host for the $S$. diacantha-S. decorata-S. plegadisi clade. Ciconiids and threskiornithids are sister groups, so it is possible that the common ancestor of Syncuaria inhabited the common ancestor of the Ciconiidae + Threskiornithidae, but corroboration of this possible cospeciation event requires better 
resolution of the basal relationships within Syncuaria. The 4 species inhabiting Podicipediformes and Pelecaniformes each appear to have arisen as a result of speciation after a hostswitching event.

The specimens of $S$. mycteriae were collected from an ailing Wood Stork found nearly moribund in an open field. Like other members of the heron family, wood storks are commonly found around open areas of freshwater and marine water, where they can wade and search for small fish and crustaceans. The other hosts of Syncuaria spp. listed above have similar piscivorous habits, and all are associated strongly with aquatic environments. We expect to find additional examples of this parasite clade as we begin to collect more aquatic birds and seabirds living in the ACG.

\section{ACKNOWLEDGMENTS}

We are grateful to the scientific and technical staff of the ACG for supporting this study, in particular, Elda Araya, Roger Blanco, Carolina Cano, Maria Marta Chavarría, Felipe Chavarría, Roberto Espinoza, Dunia Garcia, Guillermo Jimenez, Elba Lopez, Sigifredo Marin, Alejandro Masis, Calixto Moraga, Fredy Quesada, and Petrona Rios. Thanks are also due to Dan Janzen and Winnie Hallwachs, scientific advisers to the ACG, for their support. Host specimens were collected by D.C., Jeremiah Trimble (Museum of Comparative Zoology [MCZ]), and Calixto Moraga (ACG) under the authority of CITES (Commission on International Trade in Endangered Species) Permit US9258251, CITES Permit CR9123440, Costa Rica Ministero del Ambiente y Energia Licencia 203640283 and Resoluciones 215-2001-OFAU and 4112001-OFAU, Harvard University IACUC Protocol 21-09, and U.S. Department of Agriculture Animal and Plant Health Inspection Service Permit 47956 (Form VS16-6A). Host necropsy and parasite collections were made by D.R.B., D.C., Elda Araya, Sara Brant, Marie Causey, Ben Hanelt, Calixto Moraga, and Petrona Rios. This study was funded by a research grant from the Natural Sciences and Engineering Research Council of Canada to D.R.B. and by a grant from the MCZ Putnam Expedition Fund to D.C.

\section{LITERATURE CITED}

ALI, S. M. 1957. Studies on nematode parasites of fishes and birds found in Hyderabad States. Indian Journal of Helminthology 8: 1-83.

Barus, V. 1966. Nematodos parasitos de aves en Cuba. Parte I. Poeyana, Series A 22: 1-37.

, AND D. ZAJICEK. 1967. Parasitic nematodes of birds of the order Columbiformes in Czechoslovakia. Folia Parasitologica 14: 73-85.

BAYLIS, H. A. 1937. Note on Acuaria (Echinuria) decorata Cram. Annals and Magazine of Natural History 20: 436-438.

Baylis, H. A., AND R. DAubney. 1923. Notes on a new species of Acuaria (Nematoda) from the adjutant stork. Annals and Magazine of Natural History 9: 95-96.

Brooks, D. R., AND D. A. MCLennan. 2002. The nature of diversity: an evolutionary voyage of discovery. University of Chicago Press, Chicago, Illinois, $668 \mathrm{p}$.
CRAM, E. 1927. Bird parasites of the nematode suborders Strongylata, Ascaridata and Spirurata. United States National Museum Bulletin 140: $1-465$.

Digiani, M. C. 1999. First record of the genus Syncuaria (Nematoda: Acuariidae) in Argentina, with description of a new species. Folia Parasitologica 46: 139-144.

GENDRE, E. 1919. Description du male d'Echinuria leptoptili Gedoelst, dispharage parasite du marabout. Actes de la Societe Linneenne De Bordeaux 71: 45-49.

GILBERT, L. 1927. Characteristics of two nematodes of the western part of the USSR. Sbornik, Rabota po Gel'mintologii, Posvyashchennyi K. I. Skrjabin. pp. 54-61. [In Russian.]

Gretillat, S. 1970. Helminthe parasites d'animaux sauvages au Senegal. Deuxieme note. Annales de Parasitologie Humaine et Comparee 45: $279-288$.

GvozDEv, E. V., AND B. A. KasimzHANOvA. 1965. Nematode fauna of wild birds in South Kazakhstan. Materialy k Nauchnoi Konferentsii Vsesoyuznogo Obshchestva Gel'mintologov 3: 54-58. [In Russian.]

IKsanOV, K. I., AND L. K. Dikambaeva. 1962. Study of nematode infection in fish eating birds of Kirghizia. Izvestiya Akademii Nauk Kirgizskoi SSR 4: 131-137. [In Russian.]

JoGIS, V. A. 1963. Fauna of cestodes, nematodes and acanthocephalans of water and littoral birds of Pukhta environs. Ezhegodnik Obva Estestvoispytatelei Academii Nauk Eston SSR 55: 94-128. [In Estonian.]

MАСКО, J. K. 1962. Neue einer Nematode Skrjabinocara parvepapillata sp. n. aus dem Wirt Ciconia ciconia L. und Ciconia nigra L. Biologia, Bratislava 17: 440-446. [In Czech.]

- 1964. Zur fauna der Nematoden des Schartzstorches (Ciconia nigra L.) in der Slowakei (CSSR). Helminthologia 5: 21-32.

Petter, A. 1961. Un nouvel Acuariidae, Syncuaria diacantha $\mathrm{n} . \mathrm{sp}$. parasite de la spatule: Ajaja ajaja (L.). Annales de Parasitologie Humaine et Comparee 36: 765-769.

ROMAN-CHIRIAC, E. 1965. Cercetari asupra parazitofaunei pasarikihtiofage dir delta Lunrii. Analele Universitatii Bucuresti, Seria Stiintele Naturii, Biologie 14: 137-153. [In Romanian.]

Sepulveda, M. S., M. G. Spalding, J. M. Kinsella, R. D. Bjork, AND G. S. MCLaUghlin. 1994. Helminths of the roseate spoonbill, Ajaja ajaja, in southern Florida. Journal of Helminthological Society of Washington 61: 179-189.

Shigin, A. A. 1957. Parasitic worms of herons and grebes of the Rybinsk Reservoir. Trudy Darvinskogo Gosudarstvennogo Zapovednika. 4: 245-289. [In Russian.]

Skrjabin, K. I., A. A. Sobolev, AND V. M. IvashKin. 1965. Principles of Nematology 14. Spirurata of animals and man and the diseases caused by them. Part 3. Acuarioidea. Izdatel'stvo Nauka, Moscow, Russia, p. 150-168, 186-200. [In Russian.]

VAIDOVA, S. M. 1965. Helminth fauna of fish eating birds in reservoir of Kura-Araksinsk lowland of Azerbaidzan. Transactions of the Institute of Zoology Baku 24: 99-108. [In Russian.]

WANG, P. 1976. Notes on some new nematodes of suborder Spirurata from Fujian, China. Acta Zoologica Sinica 22: 393-402. [In Chinese.]

Wong, P. L., R. C. ANDERSON, AND C. M. BARTLETt. 1986. Revision of the genus Syncuaria Gilbert, 1927 (Nematoda: Acuarioidea). Canadian Journal of Zoology 64: 1186-1196. 